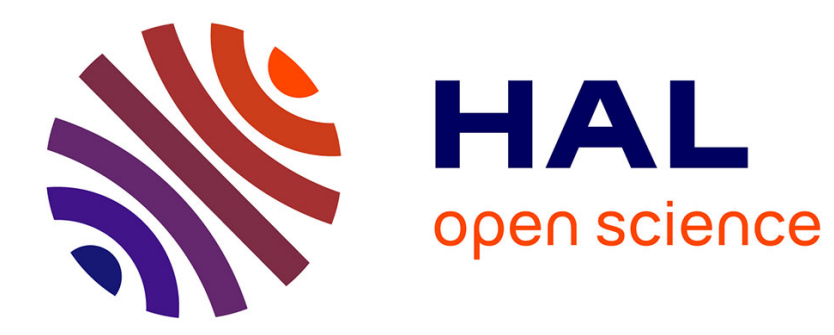

\title{
European Legal Pluralism after Kadi
}

\author{
Samantha Besson
}

\section{To cite this version:}

Samantha Besson. European Legal Pluralism after Kadi. European Constitutional Law Review, 2009, 5 (2), pp.237-264. 10.1017/S1574019609002375 . hal-02516272

\section{HAL Id: hal-02516272 \\ https://hal.science/hal-02516272}

Submitted on 3 May 2020

HAL is a multi-disciplinary open access archive for the deposit and dissemination of scientific research documents, whether they are published or not. The documents may come from teaching and research institutions in France or abroad, or from public or private research centers.
L'archive ouverte pluridisciplinaire HAL, est destinée au dépôt et à la diffusion de documents scientifiques de niveau recherche, publiés ou non, émanant des établissements d'enseignement et de recherche français ou étrangers, des laboratoires publics ou privés. 


\title{
European Legal Pluralism after Kadi
}

\author{
Samantha Besson*
}

Relationships between international, EU, domestic law - Different legal orders Different jurisdictions - Validity, rank, effects of international law in EU legal order - Kadi - Court of First Instance in Kadi - Advocate-General in Kadi - European Court of Justice in Kadi - Pluralism concept of AG Maduro - European legal pluralism reconsidered

\section{INTRODUCTION}

The relationship between European Union law (hereafter, 'EU law' or, in a more general sense, 'European law, ${ }^{1}$ ) and international law has been a concern for European and international lawyers alike for quite some years now. ${ }^{2}$ Although the

* Professor of Public International Law and European Law and co-Director of the European Law Institute, University of Fribourg (Switzerland). This article is an extensively revised version of the introductory paper I delivered on 18 April 2008 in Fribourg at the BENEFRI Conference on The Relationship between European and International Law - Old Question, New Answers?, at which some of the articles published in this issue were also presented. Many thanks to all participants, whose papers did so much to enhance the quality of the debates, and in particular to Thomas Cottier, Erika de Wet, Bruno de Witte, Helen Keller and Miguel Poiares Maduro. I would also like to thank audiences at the 3 Oct. 2008 Colloque Strasbourg-Fribourg in Strasbourg and the 21 Nov. 2008 Expert Seminar on Kadi in Amsterdam.

${ }^{1}$ Unless specified otherwise, I am not distinguishing here between European Community (hereafter, 'EC') and EU law given the increasingly inseparable nature of the law issued and of judicial review under the three pillars. One should of course regret that the ECJ focuses mostly on EC law in Kadi, thus relying on the pillar division at least in its discussion of the legal basis of the individual sanctions that were taken. Thus, the ECJ surprisingly describes ' $[. .$.$] the coexistence of the Union$ and the Community as integrated but separate legal orders [...]' (ECJ, Case C-402/05 P, Yassin Abdullah Kadi v. Council of the European Union and Commission of the European Communities [2008] ECR I-0000, par. 202).

2 See, e.g., A. Peters, 'The Position of International Law within the European Community Legal Order', 40 German Yearbook of International Law (1997) p. 9; D. Bethlehem, 'International Law, European Community Law, National Law: Three Systems in Search of a Framework', in M. Koskenniemi (ed.), International Law Aspects of the European Union (The Hague, Kluwer 1998) p. 169; K. Lenaerts and E. De Smijter, 'The European Union as an Actor under International Law', 19 Yearbook of European Law (1999) p. 95; J.C. Gautron and L. Grard, 'Rapport général: Le droit international dans 
question is a classical one, this article argues that answers that have traditionally been given ought to be revisited in the light of important changes in international and European law.

Recent developments in the European case-law since 2005, and those triggered by the Kadi case, ${ }^{3}$ provide this article's starting point. Drawing on the three decisions that were successively made in that case, the article reframes some of the legal categories used to date to describe the articulation between the international and the European legal orders and more specifically: the validity, the rank and the effects of international law within the EU legal order. There is one concept in particular that has become very popular and is widely used to capture the change of paradigm in the relationship between the international and European legal orders and, in some cases at least, to replace traditional legal categories: it is the concept of legal pluralism. That concept actually lies, for instance, at the core of the reasoning of the Advocate-General in the Kadicase and supplies the key to the exegesis of the Kadi jurisprudence. As that concept can mean different things to different people, the article will examine it more closely in order to unpack its implications within the European legal order.

la construction de l'Union européenne', in J.C. Gautron and L. Grard (eds.), Droit international et droit communautaire, perspectives actuelles, Colloque de Bordeaux (Paris, SFDI 2000) p. 11; T.C. Hartley, 'International Law and the Law of the European Union - A Reassessment', 72 British Yearbook of International Law (2001) p. 1; N. Lavranos, Legal Interaction between Decisions of International Organizations and European Law (Groningen, Europa Law Publishing 2004); M. Lickova, 'European Exceptionalism in International Law', 19:3 European Journal of International Law (2008) p. 463.

${ }^{3}$ See the Court of First Instance (CFI)'s decision: Case T-315/01, Kadiv. Council and Commission [2005] ECR II-3649, 21 Sept. 2005; Advocate-General (AG) Maduro’s opinion: Case C-402/05 P, Yassin Abdullah Kadi v. Council of the European Union and Commission of the European Communities, 16 Jan. 2008; and the European Court of Justice (ECJ)'s decision: Case C-402/05 P, Yassin Abdullah Kadi v. Council of the European Union and Commission of the European Communities, 3 Sept. 2008. Scope precludes listing the numerous publications that followed: see, e.g., D. Simon and F. Mariatte, 'Le Tribunal de première instance des Communautés: Professeur de droit international?’, 12 Revue Europe (2006) p. 6; P. Eeckhout, 'Community Terrorism Listings, Fundamental Rights, and UN Security Council Resolutions. In Search of the Right Fit', 3 European Constitutional Law Review (2007) p. 183; N. Lavranos, 'UN Sanctions and Judicial Review', in J. Wouters, A. Nollkaemper and E. de Wet (eds.), The Europeanisation of International Law: The Status of International Law within the EU and its Member States (The Hague, T.M.C. Asser Press 2008) p. 185; C. Eckes, 'Judicial Review of European Anti-Terrorism Measures - The Yusuf and Kadi Judgments of the Court of First Instance', 14:1 European Law Journal (2008) p. 74; S. Besson, 'How International is the European Legal Order? Retracing Tuori's Steps in the Exploration of European Legal Pluralism', No Foundations (2008) (<http://www.helsinki.fi/nofo/>, visited on 9 Feb. 2009); T. Tridimas and J.A. Gutierrez-Fons, 'EU Law, International Law and Economic Sanctions Against Terrorism: The Judiciary in Distress?', 32 Fordham International Law Journal (2009) p. 901; D. Simon and A. Rigaux, 'Le jugement des pourvois dans les affaires Kadi et Al Barakaat: Smart sanctions pour le Tribunal de première instance?', 11 Revue Europe (2008) p. 5; P. D’Argent, 'Arrêt « Kadi »: le droit communautaire comme droit interne', Journal de droit européen (2008) p. 265; N. Lavranos, 'Case note on Kadi, Legal Issues of Economic Integration (2009) p. 157. 
The ultimate goal of the present contribution is to develop a theoretical framework for future reflections on the relationship between a plurality of autonomous albeit overlapping international legal orders, in the first place to each other, but also ultimately and inevitably between them and national legal orders. My claim indeed is that these three autonomous layers of the European legal order lato sensu ought to be considered at the same time when assessing the articulation between any two of them. Only a few scholars have examined the issue in this integrated fashion ${ }^{4}$ and this constitutes a blind spot in contemporary legal analysis of the European legal order.

The article's argument is three-pronged. In a first section, it starts by clearly identifying the different questions raised by the relationship between the European and international legal orders and presents the answers that have traditionally been given to those questions in the European case-law. The second section turns to recent developments in practice and uncovers the new perspectives one may draw from the Kadi case in particular. In its third section, the article broaches some of the concerns European lawyers are facing post-Kadi. Drawing on those concerns, it delineates a more comprehensive approach to the relationship between the European and the international legal orders, by revisiting the contours and meanings of European legal pluralism and its implications for domestic legal orders.

\section{THE RELATIONSHIP BETWEEN INTERNATIONAL AND EUROPEAN LAW BEFORE KADI}

\section{The question}

The relationship between European and international law, and more precisely between the EU legal order and the international one, ought to be carefully distinguished from that between EU and national law and that between international and national law, on the one hand, and from that between two systems of international law, on the other.

Although EU law regards itself as an autonomous legal order whose sources and their relationship are self-identified and hence may be compared in more than one respect with a domestic legal order, it also counts states as its subjects and regards itself as an order of international law, albeit a new one. ${ }^{5}$ Its relationship to international law cannot therefore be strictly equated with that between international and national law. Nor can that relationship be identified, however, with that

\footnotetext{
${ }^{4}$ See, e.g., Betlehem, supra n. 2; Besson, supra n. 3.

${ }^{5}$ So does its Court regard the nature of the European legal order: ECJ, Case 26/62, Van Gend en Loos v. Nederlandse Administratie der Belastingen [1963] ECR 1, par. 9.
} 
between EU and national law. The European legal order is indeed an integrated legal order whose status, rank and effects in national law are determined by EU law. International and EU law are not integrated in that way, at least not independently from their respective degrees of integration within domestic legal orders. In short, the relationship between the European and international legal orders is not unilateral, but mutual; both legal orders receive each other's norms in a reciprocal way ${ }^{6}$ and if the European legal order often appears to be the one receiving international law norms, this is because the European legal order is inseparable from its member states' legal orders and hence from the implementation of both EU law and international law norms within those orders.

Their relationship cannot, however, be equated with that between two regimes of international law either. ${ }^{7}$ EU law claims to determine its own validity and hence its sources, including international law sources of EU law, autonomously. ${ }^{8}$ That autonomy is therefore autonomy from national law, but also at the same time from international law. This applies to general international law, as much as to more special areas of international regulation. In other words, the relationship between European and international law is that between two non-municipal albeit autonomous legal orders. Importantly, those two non-municipal legal orders have different relationships with municipal or domestic legal orders and their relationship to one another cannot but reflect those relationships.

The question raised by the relationship between international and European law pertains, as a result, to the European legal order's autonomy from international law and to its extent. ${ }^{9}$ More concretely, it is about whether or not it is only a matter of EU law to determine the validity, rank and effects of international law

${ }^{6}$ It suffices here to think of WTO cases in which EU law is invoked alongside WTO and general international law norms by EU member states. See the essays in J. Wouters, A. Nollkaemper and E. de Wet (eds.), The Europeanisation of International Law: The Status of International Law witbin the EU and its Member States (The Hague, T.M.C. Asser Press 2008). See also Lickova, supra n. 2, at p. 475 et seq. on Europeanized international legal norms and practises.

${ }^{7}$ Regimes of international law are ensembles of international law norms that have a specific material, personal or territorial scope which distinguishes them from other normative ensembles and from general international law, but does not imply their autonomy qua legal orders. See S. Besson, 'Theorizing the Sources of International Law', in S. Besson and J. Tasioulas (eds.), The Philosophy of International Law (Oxford, Oxford University Press 2009).

${ }^{8}$ ECJ, Case 26/62, Van Gend en Loos v. Nederlandse Administratie der Belastingen [1963] ECR 1, par. 9.

${ }^{9}$ See, e.g., J. Weiler and U. Haltern, 'The Autonomy of the Community Legal Order: Through the Looking Glass', 37 Harvard Journal of International Law (1996) p. 411. See also the 1996 SchillingWeiler/Haltern debate that ensued (<http://www.jeanmonnetprogram.org/papers/96/9610.html>, visited on 9 Feb. 2009: Who in the Law is the Ultimate Judicial Umpire of European Community Competences?). See also D. Simon, 'Rapport général: Les fondements de l'autonomie du droit communautaire', in J.C. Gautron and L. Grard (eds.), Droit international et droit communautaire, perspectives actuelles, Colloque de Bordeaux (Paris, SFDI 2000) p. 207. 
norms within the European legal order, and how it can legitimately do so. Of course, this implies clarifying the international nature of the legal norms applicable within the EU legal order, including but also besides those of primary and secondary EU law. It also means identifying the place of international law among the sources of EU law (both qua object and qua [direct or indirect] standard of review by the European Court of Justice).

Importantly, our question ought not be conflated with a connected but conceptually distinct issue: the relationship between the many international and European courts vested with jurisdiction in those different legal orders. That issue has become particularly difficult since jurisdictions have started to proliferate at the international level and to gain jurisdiction over the same sets of legal norms and within the same or overlapping personal, material and territorial scopes, without, however, developing clear rules of litispendence and resjudicata. ${ }^{10}$ Even though issues pertaining to the relationship between legal orders often arise in cases where there is also a conflict of jurisdiction or at least competing jurisdiction between two international courts, they need not. One may think of cases, such as the Kadi case, where difficult issues of delineation of legal orders arise independently of a conflict or competition between European and international jurisdictions. Another case at hand is the Mox case, ${ }^{11}$ where the relationship between the European and international legal orders was clear, but where the jurisdiction of an international arbitration tribunal was disputed by the European Court of Justice. This is not to deny that jurisdictions can have an impact on the resolution of conflicts between legal orders and on the development of rules of conflict and principles regulating their relationships, but the connection is empirical at most, not conceptual. ${ }^{12}$

${ }^{10}$ On this topic, see, e.g., N. Lavranos, 'Regulating Competing Jurisdictions among International Courts and Tribunals', 68 Zeitschrift für ausländisches öffentliches Recht und Völkerrecbt (2008)p. 575; R. Higgins, 'A Babel of Judicial Voices? Ruminations from the Bench', 55/4 International and Comparative Law Quarterly (2006) p. 791; Y. Shany, The Competing Jurisdictions of International Courts and Tribunals (Oxford, Oxford University Press 2004).

${ }^{11}$ ECJ, Case C-459/03, Commission v. Ireland (Mox plant) [2006] ECR I-4635. See also the IJzeren Rijn (Iron Rhine) Arbitration Sentence between Belgium and The Netherlands, 24 May 2005 (<http: //untreaty.un.org/cod/riaa/cases/vol_XXVII/35-125.pdf>).

12 This explains why the 'Solange' principle used by the German Federal Constitutional Court in the Solange I and Solange II decisions (Solange I BverfGE 37, 271 (1974); Solange II BVerfGE 73, 339 (1986); and Brunner BVerfGE 89, 155 (1993)), but also - albeit differently - by the European Court of Human Rights in Bosphorus (ECtHR, Bosphorus, Appl. No. 45036/98, Judgment of 30 June 2005) and by AG Maduro in Kadi ought to be understood as a principle of allocation of judicial review power between courts. An equivalence principle in terms of the mutual ordering among legal norms stemming from different legal orders may, of course, be derived from it, but it need not be identified with it and would have to be argued for separately. See Lavranos, supra n. 10 on the Solange method as an inter-jurisdictional tool. 


\section{The answers}

Questions pertaining to the autonomy of the European legal order from international law and to its extent have given rise to very different answers since the creation of the European Communities and the European Union.

Before turning to those answers, two caveats are in order. Those answers may, first of all, have to be grouped by reference to the perspective they use: that of international law or that of EU law. Answers might differ depending on the legal order of the forum. ${ }^{13}$ In certain instances, however, both perspectives may be found in the same forum: in the Kadi case, for instance, different European courts adopted alternatively an international law perspective and a European one. ${ }^{14} \mathrm{~A}$ second source of complexity, that can become source of so much fragmentation that it may even disqualify the quest for clear answers in the field, is the sheer diversity of the norms one may be referring to, both in international and EU law. Thus, among international law norms, it is important to distinguish between general and special international law and, among special international law norms, between those stemming from agreements between the European Communities (hereafter, 'EC') and member states, or between them, or either of them, and third states, or international organisations (hereafter, 'IO'), and, finally, whether those agreements pre-date the creation of the EC in 1957 or not. Within the scope of European law in general, it may be useful to distinguish between EC and EU law, and within EC law, to identify what kind of relationship between the EC (and/or member states) and third states or IOs, between the EC and member states or between member states is at stake and based on which kind of competence. $^{15}$

\section{A new legal order of international law}

Generally speaking, the EU's perspective, or more exactly that of the Court of Justice, is that the EU is an international organisation vested with international legal personality ${ }^{16}$ and that its legal order is an international legal order. ${ }^{17}$ Accord-

${ }^{13}$ See Lickova, supra n. 2, at p. 469.

${ }^{14}$ This assumes, of course, that those perspectives are necessarily in conflict and that those conflicting perspectives can co-exist without creating difficulties for national authorities. See Besson, supra n. 3, at p. 11-15 on the limits of perspectivism.

${ }^{15} \mathrm{It}$ is interesting to note that neither the CFI, the AG nor the ECJ have gone at great length into distinguishing the detailed pedigree of the international law norms and of the EU law norms whose relationship they were discussing. See, e.g., ECJ, Kadi, par. 282 referring to the UN Charter as an 'international agreement'.

${ }^{16}$ ECJ, Opinion 1/91, Draft Treaty on the establishment of a European Economic Area (EEA) [1991] $E C R$ I-6079. Note that it is the EC more specifically that is vested with legal personality, although that restrictive approach is largely contested within both EU and international law. See J. Klabbers, 
ing to the Court, however, the EU is a sui generis organisation ${ }^{18}$ and its international legal order is of a new kind. ${ }^{19}$ What makes it a new legal order (of international law) is that EU treaties, by contrast to ordinary international law treaties, have created an autonomous legal order that is integrated into national ones. ${ }^{20}$ The consequences are that the EU legal order determines its own validity and hence its sources autonomously. ${ }^{21}$ It also determines on its own what the validity, rank and effect of its norms will be in national law. ${ }^{22}$ In other words, the autonomy of the European legal order, and accordingly its innovative aspect when compared with international law, is its independence both from international and national law.

It is less clear, however, whether that autonomy also implies that the EU legal order determines on its own the validity, rank and effect of international legal norms within the EU legal order. Given that in the domestic context those questions are usually left to the domestic legal order to decide, the domestic analogy would in principle confirm the autonomy of EU law in that respect as well. However, the limitations of the domestic analogy were presented before. At the same time, the residual international nature of the EU legal order was alluded to, together with the integrated nature of EU law in the national legal order, and hence of international law once it is deemed valid in the European legal order.

Unsurprisingly, therefore, in a new legal order of international law, the extent of the autonomy of European law from international law remains largely uncertain. The few clarifications provided in the case-law of the European Court of Justice have been largely pragmatic and variable. To see more clearly through those answers and to try to systematize them, it is useful to identify, first of all, the nature and the extent of the EU's obligations under international law before turning, secondly, to the validity, rank and effects of those international law norms within the EU legal order.

'Presumptive Personality: The European Union in International Law', in M. Koskenniemi (ed.), International Law Aspects of the European Union (The Hague, Kluwer 1998) p. 231.

${ }^{17}$ ECJ, Case 26/62, Van Gend en Loos v. Nederlandse Administratie der Belastingen [1963] ECR 1, par. 9 .

${ }^{18}$ ECJ, Opinion 1/91, Draft Treaty on the establishment of a European Economic Area (EEA) [1991] ECR I-6079, par. 21.

${ }^{19}$ ECJ, Case 26/62, Van Gend en Loos v. Nederlandse Administratie der Belastingen [1963] ECR 1, par. 9 .

${ }^{20}$ ECJ, Case C-6/64, Flaminio Costa v. ENEL [1964] ECR 585, par. 8.

${ }^{21}$ ECJ, Case 26/62, Van Gend en Loos v. Nederlandse Administratie der Belastungen [1963] ECR 1, par. 9 .

${ }^{22}$ ECJ, Opinion 1/91, Draft Treaty on the establishment of a European Economic Area (EEA) [1991] ECR I-6079, par. 21. 


\section{The existence and scope of international law obligations in the European legal order}

International law obligations of the (EC and) EU may be divided into those stemming from general international law and those that arise out of special international law.

General international law is applicable in principle to all subjects of international law and in particular to both states and international organisations. As a result, the EU is bound by norms of international customary law ${ }^{23}$ and by general principles of international law. ${ }^{24}$ This includes, for instance, international human rights norms that are or have become part of international customary law. ${ }^{25}$

Based on special international law norms, the EC and EU have acquired international duties in the following cases. The first instance is that of the EC and EU's obligations stemming from international agreements concluded with third States or other international organisations (Article 300 par. 7 EC). This is the case, for instance, of association agreements concluded between the EC and third states. In the case of mixed agreements concluded by the EC and its member states, only those parts of the agreements concluded by the EC on the basis of an EC competence are regarded as binding the EC. ${ }^{26}$ A second group of obligations are those stemming from the decisions of international institutions and organs established by international agreements of the EC (Article 300 par. 7 EC a fortior).$^{27}$

A third tier includes the obligations stemming from agreements between member states themselves or between them and third states concluded before the creation of the EC in 1957 (Article $307 \mathrm{EC)}$ ), or after 1957 in areas of national competence. ${ }^{28}$ Those agreements remain in force despite accession of the member states to the EC, or respectively of the development of EC competences in the area. Member states' obligations deriving from pre-accession (respectively, preEC competence) agreements may accordingly authorise them to derogate to EU primary law. ${ }^{29}$ Member states have a duty, however, to reform their prior obligations so as to put them in conformity with their obligations as EC members, or

${ }^{23}$ ECJ, Case C-162/96, A. Racke [1998] ECR I-365, par. 45; ECJ, Case C-286/90, Poulsen and Diva Navigation [1992] ECR 1-6019; ECJ, Case C-405/92, Mondiet [1993] ECR I-6133; ECJ, Case C-308/06, International Association of Independent Tanker Owners (Intertanko) v. Secretary of State for Transport [2008] ECR I-0000, par. 52; ECJ, Case C-203/07 P, Greece v. Commission, [2008] ECR I-0000.

${ }^{24}$ CFI, Case T-115/39, Opel Austria [1997] ECR II-39.

25 See T. Ahmed and I. de Jesus Butler, 'The European Union and Human Rights: An International Perspective', 17:4 European Journal of International Law (2006) p. 771.

${ }^{26}$ ECJ, Case C-459/03, Commission v. Ireland (Mox plant) [2006] ECR I-4635.

${ }^{27}$ ECJ, Case C-192/89, Sevince [1990] ECR I-3461 ; ECJ, Case C-188/91, Deutsche Shell [1993] ECR I-363.

${ }^{28}$ See the discussion in Lickova, supra n. 2, at p. 472-475; I. Klabbers, 'Moribund on the Fourth July: The Court of Justice on Prior Agreements of the Member States', 26 European Law Review (2001) p. 187.

29 See, e.g., ECJ, Case C-124/95, The Queen, ex parte Centro-Com Srl v. HM Treasury and Bank of England [1997] ECR I-114, par. 59-61. 
even to denounce those agreements in certain cases. ${ }^{30}$ In principle, the EC itself incurs no direct obligations stemming from those agreements. At most, the latter generate indirect (positive and negative) obligations for the EC to its own member states, based on Article $10 \mathrm{EC}$, to make sure they can abide by their prior commitments. Those indirect obligations may lead, for instance, to duties of convention-compliant interpretation of EC law by the Court. ${ }^{31}$ Another possibility would be for certain agreements to become general principles of EU law, as it has been the case for the European Convention of Human Rights (hereafter, 'ECHR') and other international law sources of EU fundamental rights. ${ }^{32}$

There is an exception, however, and that is when the EC can be said to have de facto succeeded to its member states' obligations under those Conventions. ${ }^{33}$ This is the case if all member states were part of the agreement, they aimed at delegating some of their obligations to the EC when transferring all the corresponding competences to it, the $\mathrm{EC}$ adheres to the aims of that agreement and the practice adopted by the EC since the transfer of competences coincides with third states' expectations. Needless to say, those conditions are difficult to meet and cases of de facto succession confirmed by the Court have been rare to date. ${ }^{34}$

\section{The validity, rank and effects of international law obligations in the European legal order}

Turning to the ways in which the EU's international legal obligations can be said to become part of the EU legal order, it is useful to refer to three traditional dimensions of the articulation between the international or the European legal order, on the one hand, and the national legal order, on the other: validity, rank and effect. ${ }^{35}$ In practice, the main characteristic of the Court's case-law in this context is its pragmatism. ${ }^{36}$

30 See, e.g., ECJ, Case 812/79, Attorney General v. Juan C. Burgoa [1980] ECR 2787; ECJ, C-62/98, Commission v. Portugal [2000] ECR I-5215. See also the more stringent duties to renegotiate or denounce in Arts. 10 par. 6 and 12 of the Act of Accession of the Czech Republic, Estonia, Cyprus, Latvia, Lithuania, Hungary, Malta, Poland, Slovenia and the Slovak Republic, OJ [2003] L 236/33.

${ }^{31}$ ECJ, Case C-308/06, International Association of Independent Tanker Owners (Intertanko) v. Secretary of State for Transport [2008] ECR I-0000, par. 52; ECJ, Case C-91/05, Commission v. Council [2008] ECR I-0000; CFI, Case T-2/99, T. Port v. Council [2001] ECR II-2093; CFI, Case T-115/39, Opel Austria [1997] ECR II-39.

32 ECJ, Case 36/75, Roland Rutili v. Ministre de lintérieur [1975] ECR 1219.

${ }^{33}$ ECJ, Joined Cases 21-24/72, International Fruit [1972] ECR 1219, par. 7-18.

${ }^{34}$ For a recent discussion, see ECJ, Case C-308/06, International Association of Independent Tanker Owners (Intertanko) v. Secretary of State for Transport [2008] ECR I-0000, par. 48-9; ECJ, Case C-188/07, Commune de Mesquer [2008] ECR I-0000, par. 85.

${ }^{35}$ For recent discussions of those traditional principles and their current validity, see the essays in A. Nollkaemper and J. Nijman (eds.), New Perspectives on the Divide between International Law and National Law (Oxford, Oxford University Press 2007). See also the discussion in Besson, supra n. 3.

${ }^{36}$ For a detailed analysis up to 1997, see Peters, supra n. 2. 
With respect to the validity of international law within the EU legal order, the answers have varied. The case-law oscillates between granting immediate validity to international law within the EU legal order in most cases, thus following a monist approach, ${ }^{37}$ on the one hand, and mediated validity through incorporation or transformation of international legal norms into EU law on a more dualist model, on the other. ${ }^{38}$ In 1997, the European Parliament clearly stated its preference for a dualist model along the lines of the dualism practised by the constitutional orders of some of its member states. ${ }^{39}$ That preference was not followed by a clear legislative or constitutional choice, however, and the practice remained uncertain until recently, as we will see. This is particularly evident with respect to general international law, whose validity in the European legal order is generally regarded as immediate. ${ }^{40}$

Turning to the ranking of international law norms within the EU legal order, the principle that is generally accepted and followed in practice is that international law norms are to be ranked between EU primary law and general principles of EU law, on the one hand, and EU secondary law, on the other. This is what may be derived from a joint reading of Article 300 par. 6 and 7 EC. ${ }^{41}$ That reading has actually been confirmed in cases of annulment of acts of conclusion of international agreements by the EC that were contrary to EU primary law and EU fundamental rights in particular. ${ }^{42}$

However, even in cases where the rank of an international legal norm is clearly inferior to that of primary EU law and where the Court could therefore rely on a formal hierarchy of norms, the Court often uses compliant interpretation of EU law to minimise potential conflicts and this implies granting international law a preventive form of primacy. ${ }^{43}$ Moreover, it follows from the case-law on the status of general international law, and in particular international customary law within the EU legal order, that those norms of international law are not usually ranked

${ }^{37}$ ECJ, Case 181/73, Haegeman v. Belgium [1974] ECR 449, par. 5; ECJ, Case 12/86, Demirel v. Stadt Schwäbisch Gmünd [1987] ECR 3719, par. 7.

${ }^{38}$ ECJ, Case C-104/81, Hauptzollamt Mainz v. Kupferberg [1982] ECR 3641, par. 14-15.

${ }^{39}$ European Parliament's Resolution of 2 Oct. 1997 on the relationship between international law, Community law and the constitutional law of the Member States, OJ [1997] C 325.

${ }^{40}$ See ECJ, Case C-308/06, International Association of Independent Tanker Owners (Intertanko) v. Secretary of State for Transport [2008] ECR I-0000, par. 52; ECJ, Case C-203/07 P, Greece v. Commission [2008] ECR I-0000.

${ }^{41}$ See on the primacy of international agreements over EU secondary law, ECJ, Case C-61/94, Commission v. Germany [1996] ECR I-4006, par. 52; ECJ, Case C-311/04, Algemene Scheeps Agentuur Dordrecht [2006] ECR I-609.

42 See ECJ, Case C-327/91, France v. Commission [1994] ECR I-3641; ECJ, Case C-122/95, Germany v. Council [1998] ECR I-973.

43 See, e.g., ECJ, Case C-91/05, Commission v. Council [2008] ECR I-0000.

${ }^{44}$ ECJ, Case C-162/96, A. Racke [1998] ECR I-365, par. 45; ECJ, Case C-286/90, Poulsen and Diva Navigation [1992] ECR 1-6019, par. 9. 
below EU primary law. ${ }^{44}$ This leaves the question of a potential conflict between EU primary law and general international law open. Finally, jus cogens norms are imperative in a regime- and order-transitive way. As a result, from an international legal perspective at least, they ought to be ranked higher than non-imperative norms of EU primary law in case of conflict. ${ }^{45}$ Unless one is ready to accept the existence of regional jus cogens, the transitivity of this kind of material normative hierarchies across legal orders defeats a clear formal ranking between international and European constitutional law.

Finally, the question of the direct applicability and invocability of international law before EU authorities, and in particular the Court, is resolved by reference to criteria developed in EU law for the direct effect of EU legal norms within domestic law. ${ }^{46}$ In a nutshell, two conditions have to be met. First of all, if the parties to the international agreement have expressly granted direct effect to some of its provisions, this is how the international norms in question ought to be applied both in international law and within the European legal order. Secondly, in the absence of clear intent on the part of the parties, if the treaty's nature and aims in general allow it, on the one hand, and if the international legal norm at hand foresees individual rights and obligations and can be regarded as sufficiently clear, precise and unconditional, ${ }^{47}$ on the other, that norm is deemed by the Court to be of direct effect. However, because what is at stake here is the direct invocability of international legal norms in lieu of EU law norms, the case-law has been largely incoherent to date and reacts to the specific circumstances in each case. As a matter of fact, it is pertaining to the direct effect of WTO law and the WTO Dispute Settlement Body rulings that the Court has given the most fluctuating answers. ${ }^{48}$ Explanations for those differences are usually said to lie in the division of competence, the principle of reciprocity and the horizontal and vertical separation of powers, but other reasons may also be ventured. ${ }^{49}$

45 See Peters, supra n. 2.

${ }^{46}$ See ECJ, Case C-120/06 and 121/06 P, FLAMM and FIAMM Technologies v. Council and Commission and Giorgio Fedon \& Figli Spa and Fedon America v. Council and Commission [2008] ECR I-0000; ECJ, Case C-104/81, Hauptzollamt Mainz v. Kupferberg [1982] ECR 3641, par. 14.

${ }^{47}$ ECJ, Case C-344/04, LATA and ELFAA [2006] ECR I-403, par. 39; ECJ, Case C-308/06, International Association of Independent Tanker Owners (Intertanko) v. Secretary of State for Transport [2008] ECR I-0000, par. 45 and 64.

${ }^{48}$ ECJ, Case C-122/95, Germany v. Council [1998] ECR I-973; ECJ, Case C-149/96, Portugalv. Council [1999] ECR I-8395; ECJ, Case C-93/02 P, Biret International v. Council [2003] ECR I-10497; ECJ, Case C-377/02, Léon Van Parys NV v. Belgische Interventie- en Restitutiebureau [2005] ECR I-1465; ECJ, Joined Cases C-120/06 and 121/06 P, FLAMM and FIAMM Technologies v. Council and Commission and Giorgio Fedon \& Figli Spa and Fedon America v. Council and Commission [2008] ECR I-0000. The only exceptions have been clearly delineated in ECJ, Case C-70/87, Fediol v. Commission (Fediol III) [1989] ECR 1781; ECJ, Case C-69/89, Nakajima v. Council [1991] ECR I-2069.

49 See Peters, supra n. 2, at p. 58-66; See I. Klabbers, 'International Law in Community Law: The Law and Politics of Direct Effect', 21 Yearbook of European Law (2002) p. 263; A. von Bogdandy, 


\section{THE RELATIONSHIP BETWEEN INTERNATIONAL AND EUROPEAN LAW ACCORDING TO KADI}

\section{The background to Kadi}

Recent developments in the international legal order have enhanced the risk of conflicts between norms stemming from the European and the international legal orders. The consolidation of international law, together with changes in its personal and material scope, but also in its degree of normativity, have enhanced material and personal overlaps and interference with EU law and hence the likelihood of normative conflicts. And the same may be said about the consolidation of EC and EU competences and hence of European law. It suffices here to mention the multiplication of interactions between EU law and the ECHR, ${ }^{50}$ between EU law and WTO law and rulings ${ }^{51}$ or between EU law and UN Security Council resolutions. ${ }^{52} \mathrm{New}$ areas of contact between EU law and international law are developing fast and one may mention environmental law, foreign investment law, labour law, law of the sea ${ }^{53}$ and asylum law.

It is in the context of the conflict between UN law and EU law that the Kadi case arose. The case was brought by a person, Mr Kadi, suspected of supporting terrorism, and listed as such in the EC Regulation 881/2002 freezing his assets. That Regulation reflected UN Security Council Resolutions establishing smart sanctions against individuals suspected of belonging to Al-Qaida and included the list of names of persons involved that were identified by the UN Sanctions Committee and set up by those Resolutions. ${ }^{54}$ Kadi sought the annulment of the EC regulation based, among other grounds, ${ }^{55}$ on the breach of EU fundamental

'Pluralism, Direct Effect and the Ultimate Say: On the Relationship between International and Domestic Constitutional Law', 6:3\&4 Journal of International Constitutional Law (2008) p. 397, at p. 404 et seq.

50 See, e.g., ECJ, Case 36/75, Roland Rutili v. Ministre de l'intérieur [1975] ECR 1219; ECJ, Case C-84/95, Bosphorus v. Minister for Transport, Energy and Communications, Ireland and the Attorney General [1996] ECR I-3953; ECJ, Case C-450/06, Varec [2008] ECR I-0000.

51 See, e.g., decisions mentioned in n. 48.

52 Besides the Kadi case, see, e.g., CFI, Case T-253/02, Ayadi v. Council [2006] ECR II-2139; CFI, T-49/04, Hassan v. Council and Commission [2006] ECR II-52; CFI, Case T-228/02, People's Mojabedin Organization of Iran v. Council of the European Union [2006] ECR II-4665; CFI, Case T-47/03, Sison v. Council [2007] ECR I-0000. For a complete list, see Simon and Rigaux, supra n. 3, at p. 11.

53 See, e.g., ECJ, Case C-459/03, Commission v. Ireland (Mox plant) [2006] ECR I-4635; ECJ, Case C-308/06, International Association of Independent Tanker Owners (Intertanko) v. Secretary of State for Transport [2008] ECR I-0000.

54 The Kadi decision was in its first phase (before the CFI) replicated in another similar decision pertaining to a similar set of facts, that of Yusuf (CFI, Case T-315/01, Yusuf, ECR II-3649). When the Kadi decision was appealed, the appeal in Yusuf was dropped.

${ }^{55}$ For reasons of clarity, I am not considering other aspects of the Kadi jurisprudence. On those, see, e.g., D’Argent, supra n. 3; Lavranos 2009, supra n. 3. 
rights and in particular of his right to a fair trial and his right to private property.

The Kadi case also arose in a context of constitutional debate within both European and international law. This constitutional trend is at least in part a consequence of the increasing overlap between international and/or EU law and national law in their personal and material scopes. ${ }^{56}$ It aims at compensating the loss of constitutional autonomy of national law or at least at legitimating the increasing impingements of international and European law within the material and personal sphere of national law and especially its impact on individuals. In this context, the concept of constitutional pluralism has proven particularly attractive. ${ }^{57}$

Given the prevalence of the constitutional debate within both European and international law, it should come as no surprise that the Kadi case, with its sensitive question of fundamental rights protection, was interpreted as a first step towards the constitutionalisation (and Europeanisation) of international law by international lawyers and as the confirmation of the constitutional autonomy of EU law by European lawyers. ${ }^{58}$ As a matter of fact, the concepts and language used in the Kadi decision could be understood as a clear departure from the Court's pragmatic approach to the relationship between European and international law. Even if one decides not to read too much into the constitutional language of the case, ${ }^{59}$ so much has become clear: it would be much regretted were the Court to relapse into old habits in future cases.

\section{The perspective of the Court of First Instance}

In its 21 September 2005 decision, the Court of First Instance (CFI) rejected the action for annulment on the basis that the challenged regulation applied a UN Security Council resolution and hence fell outside of the ambit of its judicial review power. In its decision, the CFI identifies two questions which it takes up in turn: first of all, the Community's obligations under UN law and, second, the relationship between UN law and EC law.

\footnotetext{
${ }^{56}$ See, e.g., S. Besson, 'The Authority of International Law - Lifting the State Veil', 31:3 Sydney Law Review (2009) forthcoming.

${ }^{57}$ See, e.g., N. Walker, 'The Idea of Constitutional Pluralism', 65 Modern Law Review (2002) p. 317. See the recent restatement of the debate by M. Avbelj, 'Questioning EU Constitutionalisms', 9:1 German Law Journal (2008) p. 1 (<http://www.germanlawjournal.com/pdf/Vol09No01/PDF_ Vol_09_No_01_1-26_Articles_Avbelj.pdf >, visited on 9 Feb. 2009).

58 See, e.g., C. Möllers, 'Das EuGH konstitutionalisiert die Vereinten Nationen', Europarecht (2006) p. 426; Lavranos 2009, supra n. 3.

${ }^{59}$ Of course, some may regard the ECJ decision as a one-off decision due to special circumstances, reflecting a power struggle between EU institutions, between those institutions and member states, and even within the ECJ itself. See, however, the recent CFI decision in Case T-284/08, People's Mojabedin Organization of Iran v. Council of the European Union [2008] ECR I-0000; and the many other actions of the same kind brought in during the second half of 2008 and currently pending before the CFI.
} 
According to the CFI, the EC's duties result in this case from the combination of member states' duties under the UN Charter and Article 307 EC. The CFI refers to the hierarchy of norms of international law set by Article 103 UN Charter. According to Article 103 UN Charter, member states' obligations under the UN Charter prevail over any other international obligations they may have, including EU law obligations. When read together with Article 25 UN Charter, the primacy of UN law includes UN Security Council resolutions. ${ }^{60}$ Since Article 307 EC allows member states to give precedence to pre-EC Treaty obligations, member states are entitled under EC law to give priority to their international duties under UN law, the CFI argues. They may, as a result, leave unapplied any provision of EC law (even primary law) that contradicts their duties under UN law. ${ }^{61}$

Even though, unlike its member states, the EC is not bound directly by the Charter as a matter of international law, it is as a matter of EC law: $:^{62}$ the EC has indeed succeeded to its member states' duties under the Charter pertaining to areas in which it has taken over their competences. ${ }^{63}$ As a result, the EC ought not be the cause of infringements of the obligations of its member states under the UN Charter. It should in fact, in the exercise if its own competences, enable its member states to fulfil their international obligations. ${ }^{64}$ The CFI then argues that, since the EC had no margin of appreciation when implementing the UN Security Council Resolutions at stake, reviewing the compatibility of the EC regulation with EU fundamental rights would imply reviewing the legality of a UN Security Council Regulation, thus not only violating member states' duties under international law, but also the Community's duties under EC law.

Turning to what this implies for the relationship between European and international law, the CFI's reasoning reflects a monist approach according to which valid international law is also immediately valid within EU law. ${ }^{65}$ It is a clear-cut argument that ought to be contrasted with the ECJ's prior case-law in this respect. In terms of rank, the CFI transposes the formal hierarchy of international law norms set by Article 103 UN Charter within EU law. As a result, UN law is granted primacy over all other sources of EU law, including EU primary law. In this respect, the CFI also clearly departs from the ECJ's previous case-law discussed before.

The only exception to the primacy of international law that is granted by the CFI is the case in which international law norms violate international jus cogens

${ }^{60}$ CFI, Kadi, par. 183-4.

${ }^{61}$ CFI, Kadi, par. 190.

${ }^{62}$ CFI, Kadi, par. 193 and 207.

${ }^{63}$ CFI, Kadi, par. 193, 199-203 by reference to ECJ, Joined Cases 21-24/72, International Fruit [1972] ECR 1219.

${ }^{64} \mathrm{CFI}$, Kadi, par. 204.

${ }^{65} \mathrm{CFI}$, Kadi, par. 224. 
norms. Those norms apply to all international law subjects, including the UN, and hence take priority over the formal hierarchy of norms applying within the UN, and accordingly within EU law. If international jus cogens norms were to be violated, the CFI would have the competence to review the international legality of international law norms within the EU legal order. ${ }^{66}$ As there was no violation of jus cogens in the case at hand, ${ }^{67}$ the CFI rejected the action in annulment. Mr Kadi appealed against the CFI judgment before the ECJ.

\section{The perspective of the $A G$}

On 16 January 2008, Advocate-General Maduro issued his opinion, disagreeing with the CFI both on the outcome and the reasoning. The EC regulation at stake violated EU fundamental rights and ought therefore to be annulled.

The Opinion is very clear about the central question of the case being the articulation between the two legal orders. ${ }^{68}$ Setting the scene the way he does, however, Maduro turns the question into a pure question of EU law. This enables him to escape a discussion of the CFI's point about the applicability of Article 103 UN Charter's international formal hierarchy of norms within EU law, or the rank of jus cogens within the international hierarchy of norms, and to circumvent the possibility of a review by the ECJ of international law (e.g., when the latter violates international human rights and may be regarded as ultra vires).

Maduro adopts the same sequence of questions as in the CFI's decision, but gives very different answers: he assesses, first of all, what the EC's duties are under UN law, before turning, secondly, to the relationship between UN law and EU law.

According to Maduro, the EC is not bound by the UN Charter and by UN Security Council resolutions. The CFI's de facto succession argument cannot be made successfully pertaining to the UN. As a matter of fact, Article 307 EC creates duties for member states to make sure they can abide by their EC obligations. Of course, the EC shares many of the UN's aims and ought to make sure its member states can abide by their obligations under UN law. ${ }^{69}$

In terms of the relationship between European and international law, the opinion adopts a dualist, or, more exactly, as I will argue, a pluralist approach to international law given Maduro's other writings on the subject. ${ }^{70}$ Even in cases in which

${ }^{66} \mathrm{CFI}$, Kadi, par. 226.

${ }^{67} \mathrm{CFI}$, Kadi, par. 243 and 286.

${ }^{68}$ AG, Kadi, par. 25.

${ }^{69}$ AG, Kadi, par. 21-4, 30.

${ }^{70}$ See, e.g., M. Maduro, 'Contrapunctual Law: Europe's Constitutional Pluralism in Action', in N. Walker (ed.), Sovereignty in Transition (Oxford, Hart Publishing 2003) p. 501; M. Maduro, 'Interpreting European Law: Judicial Adjudication in a Context of Constitutional Pluralism', European Journal of Legal Studies (2007) p. 1. 
the EC is bound by international law, Maduro considers that ' $[t]$ he relationship between international law and the Community legal order is governed by the Community legal order itself, and international law can permeate that legal order only under the conditions set by the constitutional principles of the Community. ${ }^{71}$ Turning to the question of the rank of international law norms once they have been authorised by EC law to permeate the European legal order, the AdvocateGeneral places EU constitutional law norms above those of international law. This means that EU fundamental rights take priority over EC obligations under international law. ${ }^{72}$ In the case at hand, the EC Regulation violated EU fundamental rights and ought therefore to be annulled. The Advocate-General's reasoning then becomes pluralist again, but in a different way: he concludes by qualifying the ECJ's power of judicial review and by conditioning it to the absence of an equivalent level of protection of fundamental rights and judicial review system under the current $\mathrm{UN}$ regime. ${ }^{73}$

\section{The perspective of the European Court of Justice}

In its highly awaited judgment of 3 September 2008, the ECJ followed the conclusions of the Advocate-General in its outcome and concluded to the annulment of the EC Regulation on the basis of a violation of EU fundamental rights. ${ }^{74}$ It therefore reversed the CFI's judgment.

The ECJ does not, however, follow the exact same reasoning - nor does it, as a matter of fact, provide a very clear explanation as to how it gets to its conclusions. Whereas the Advocate-General is very open about the relationship between orders and makes it the focal point of his opinion, the ECJ is less explicit, probably intentionally so. Instead, the ECJ focuses on its own competence to review the legality of an EC Regulation based on UN Security Council Resolutions by reference to the EU's 'constitutional charter, ${ }^{75}$ and addresses the more general questions of articulation between legal orders from that perspective only. ${ }^{76}$

To start with, the ECJ is very clear as to the boundaries set on the member states' own duties stemming from pre-1957 agreements. Even though it recognises some of the EC's duties under Article 307 EC vis-à-vis its member states and reit-

${ }^{71}$ AG, Kadi par. 24.

${ }^{72}$ AG, Kadi, par. 24 and 21: '[The Court] considered that the Treaty had established a 'new legal order', beholden to, but distinct from the existing legal order of public international law. In other words, the Treaty has created a municipal legal order of trans-national dimensions, of which it forms the "basic constitutional charter".' [emphasis added].

${ }^{73}$ AG, Kadi, par. 44 and 54.

${ }^{74}$ ECJ, Kadi, par. 334.

${ }^{75}$ ECJ, Kadi, par. 281.

${ }^{76}$ ECJ, Kadi, par. 282, 285. 
erates the possibility for them to derogate from primary EC law to fulfil their pre1957 international commitments, ${ }^{77}$ it rejects the possibility of them using that provision to invoke the priority of those obligations over 'the principles that form part of the very foundations of the Community legal order, one of which is the protection of fundamental rights, including the review by the Community judicature of the lawfulness of Community measures as regards their consistency with those fundamental rights. ${ }^{78}$ By contrast, the ECJ does not address in detail the question whether the EU has any obligations under UN law. It does not, as a result, fully debunk the CFI's argument regarding the EC's de facto succession to some of its member states' duties under the UN Charter. It merely rejects the possibility for those duties, were they to exist, to take priority over EU fundamental rights, based on a discussion of the validity and rank of international duties in EU law.

As this stage, the ECJ turns hypothetical and envisages the case in which the EC were bound by a UN Security Council resolution. ${ }^{79}$ The articulation between the international and European legal orders in such a case would clearly follow a dualist model (rather than a monist one) ${ }^{80}$ it is up to EC law to determine the conditions under which the 'transposition' ${ }^{81}$ of international law can take place, and hence the validity of international law as a source of EC law within the EU legal order. This follows a fortiori from the ECJ's considerations about the 'internal and autonomous legal order of the Community ${ }^{82}$ as being distinct from the international legal order ${ }^{83}$ and about the ECJ's power to review the compatibility between EC law and the constitutional guarantees of EC law, a constitutional power that is unaffected by international law. ${ }^{84}$

According to the ECJ, the rank of international law within the European legal order is determined by EC law and in particular by Article 300 paras. 6 and 7 EC. It is intermediary and international law norms are subordinated to EU primary

${ }^{77}$ ECJ, Kadi, par. 301.

${ }^{78}$ ECJ, Kadi, par. 304 [emphasis added], 303.

${ }^{79} \mathrm{See}$ ECJ, Kadi, par. 305 et seq. It is extremely unlikely in any case that Art. 300 par. 6 or 7 EC could have been thought to be applicable to the UN Charter or UN Security Council Resolutions, i.e., international agreements to which the EC is not a party.

${ }^{80}$ See, for a confirmation, Simon and Rigaux, supra n. 3, at p. 8.

${ }^{81}$ ECJ, Kadi, par. 298.

${ }^{82}$ ECJ, Kadi, par. 317.

${ }^{83} \mathrm{See}$ ECJ, Kadi, par. 288: 'However, any judgment given by the Community judicature deciding that a Community measure intended to give effect to such a resolution is contrary to a higher rule of law in the Community legal order would not entail any challenge to the primacy of that resolution in international law.' [emphasis added].

${ }^{84}$ ECJ, Kadi, par. 316: ' $[. .$.$] [T] he review by the Court of the validity of any Community mea-$ sure in the light of fundamental rights must be considered to be the expression, in a community based on the rule of law, of a constitutional guarantee stemming from the EC Treaty as an autonomous legal system which is not to be prejudiced by an international agreement.' 
law, including EU constitutional principles and EU fundamental rights (qua general principles of EU law). ${ }^{85}$ Interestingly, this allows the ECJ to distinguish a superior tier of constitutional law within EU primary law, a tier constituted by EU constitutional principles and fundamental rights. ${ }^{86}$ Regrettably, however, the ECJ does not address the jus cogens issue raised by the CFI, except to disparage it, ${ }^{87}$ nor the possibility under certain circumstances for the ECJ to review international law norms directly.

Like the Advocate-General, the ECJ opts for a Europe-centred approach: the review of the validity of EU law by reference to EU constitutional principles. ${ }^{88}$ However, the ECJ does not reiterate the Advocate-General's Solange argument and his application of the equivalence principle.

\section{THE RELATIONSHIP BETWEEN INTERNATIONAL AND EUROPEAN LAW AFTER KADI}

In Kadi, the CFI openly opted for a monist approach to the relationship between international and European law; international law is immediately valid within the European legal order. It also clearly chose to integrate the international hierarchy of norms - or at least that of Article 103 UN Charter - within the European legal order and hence to grant primacy to international law over any European legal norm (with the exception of violations of jus cogens). By contrast, it came out of the previous presentation of the Advocate-General's opinion and of the ECJ's decision in Kadi that both of them seemed to have rejected the monist model, allowing international law norms to gain validity in EU law only if they comply with EU constitutional primary law and in particular with EU fundamental rights. The Advocate-General consciously addressed the question of the articulation between legal orders and used a pluralist model to do so. By contrast to both the Advocate-General and the CFI, the ECJ did not directly address the question of the relationship between orders, but only that of the scope of its review power, and, at least on the face of it, opted for a more classical dualist approach to the relationship between European and international law.

${ }^{85}$ ECJ, Kadi, par. 306-8.

${ }^{86}$ It remains unclear whether the ECJ's statement in Centro-Com (ECJ, Case C-124/95, The Queen, ex parte Centro-Com Srl v. HM Treasury and Bank of England [1997] ECR I-114, par. 59-61) pertaining to the possibility for member states to derogate from EU primary law through preaccession agreements remains valid outside of the constitutional layer in EU primary law. Drawing a clear line between constitutional and non-constitutional primary law would in any case probably be quite difficult in practice. See the discussion in Lavranos 2009, supra n. 3.

${ }^{87}$ ECJ, Kadi, par. 287 and 327-9.

88 See ECJ, Kadi, par. 314-7, 326. 
The constitutional model for the relationship between the European and international legal orders spelled out in the ECJ's decision in Kadi is still in need of a lot of clarification. Its three key dimensions (validity, rank and effect) have to be considered and assessed in more detail. And not only in the bilateral relationship between the European and the international legal orders as they have been so far, but also with respect to their impact on the relationship between national and international law, on the one hand, and between national and EU law, on the other.

To do so, I would like to start by discussing some of the immediate and concrete consequences of the Kadi case-law for member states and identifying the concerns raised by what one may refer to as 'European monist dualism', i.e., the imposition of dualism in national legal orders in their relationship to international law as a consequence of EU law's imposed monism in its relationship to national law. On that basis, I will then return to the general question of the relationship between the European and the international legal orders, by revisiting the contours and meaning of European legal pluralism post-Kadi and by defending an approach which one may refer to as 'European pluralist dualism'.

\section{European monist dualism de lege lata}

In the Kadi case, both the Advocate-General and the European Court of Justice have referred to the EU legal order as an 'internal' ${ }^{89}$ or 'municipal' ${ }^{90}$ legal order. This stance about the municipal nature of the autonomous European legal order allows them to isolate the relationship between European and international law as one would isolate the relationship between European and national law or between international and national law. However, this should not obfuscate the fact that, in an integrated legal order like the European legal order, national law remains central to the reception of both EU law and international law; if the European legal order can be described as internal, it is precisely because there is a national legal order that integrates EU legal norms (and any international norm that has become part of EU law) and give them primacy. The relationship between European and international law cannot therefore but affect the relationship between EU and national law, on the one hand, and that between international and national law, on the other.

If this is the case, the 'ménage à trois' between the three legal orders ought to be taken into account whenever a bilateral relationship between either two of them is assessed. It is a concern the CFI may have had, but not one that was taken aboard expressly either by the Advocate-General or the ECJ. ${ }^{11}$ It is too early to

${ }^{89}$ ECJ, Kadi, par. 317 and 321.

${ }^{90}$ AG, Kadi, par. 21.

${ }^{91}$ This is not to say, of course, that the concern was not taken seriously behind the scenes. Intense dialogue took place between the ECJ and national supreme courts, especially at the time of the constitutional review of the Lisbon Treaty by many of those courts. See, e.g., AG, Kadi, fn. 34. 
say what the impact of the ECJ's decision in Kadi will be on the member states' legal orders.

With respect to its impact on the relationship between EU and national law, first of all, it might seem difficult at first sight to explain what justifies applying a dualist model to the external relations of the EU and a monist one to its internal relations with national legal orders in the long run. The immediate validity of EU law within national legal orders is indeed a constitutive principle of the European legal order. ${ }^{92}$ Some member states may be tempted to use the re-emergence of dualism in the case-law of the European Court of Justice to rebel against imposed monism of EU law within the 'internal' European legal order. I will assess those claims in the next section from a more normative perspective.

The impact of the Court's decision in Kadi on the relationship between national and international law, secondly, is more difficult to assess at this stage. ${ }^{93}$ Qua internal or integrated legal order, the European legal order cannot afford to adopt a dualist approach vis-à-vis international law that would not be followed by its constitutive national legal orders. The principle of primacy of EU law within the European legal order does not allow it. The imposed monism and primacy of EU law within the domestic legal order and the forced dualism this implies vis-à-vis international law, may, however, create difficulties for those member states that have traditionally adopted a monist approach in their relationship to international law. ${ }^{94}$ The reverse may also be true. Dualist states would have to abide by international law norms deemed valid by EU law if they respect EU constitutional primary law, even though they do not comply with national constitutional requirements. Furthermore, the conditional primacy of international law in EU law, i.e., the fact that it is ranked below the constitutional tier of EU primary law and can never take priority over it, could also, when it is coupled with the absolute primacy of EU law, create difficulties for states which grant absolute primacy to international law, even over national constitutional law. ${ }^{95}$

Different legal situations ought to be distinguished in which one may see a Kadi-based form of EU law-induced dualism between national and international law at work. The first type of cases has already been decided upon by the Court in

92 See ECJ, Case C-6/64, Flaminio Costa v. ENEL [1964] ECR 585, par. 8.

${ }^{93}$ Note that it is mostly regarding pre-1957 (or pre-EC competence) norms of international law that the question arises.

${ }^{94}$ Interestingly, there have been three decisions of the Swiss Federal Tribunal on similar facts to Kadi since Oct. 2007. They have followed the CFI's reasoning in Kadi and a strict monist approach with primacy granted to international law (ATF 133 II 450 (Nada); 2A.783(4,5)/2006 (A); 1A.48/ 2007 (A)). As the Nada case is now pending before the European Court of Human Rights, one may hope to see the Bosphorus reasoning applied to the UN in circumstances closer to those of the Kadi case than to the Behrami decision.

${ }^{95}$ This would be the case in a country like Switzerland, as exemplified in the Nada case (n. 94). 
Ayadi ${ }^{96}$ and other decisions in its wake. It pertains when a member state applies both a UN Security Council resolution and an EC regulation, but is granted a certain margin of appreciation. In such a case, the member state is clearly constrained by EU primary law and EU fundamental rights in particular, and would have to invalidate contrary national law in spite of its international law obligations.

In a second type of case, member states are bound by a UN Security Council Resolution and an EC regulation applying it, but lack any margin of appreciation. Here again two situations could arise. In the first situation, along the lines of the $O M P I^{97}$ case, the EC Regulation in question has been adopted within the EC's margin of appreciation and is bound to respect EC primary law and EU fundamental rights in particular. In such a case, member states that doubt the validity of the regulation but cannot themselves review it under the Foto-Frost principle, ${ }^{98}$ have to start an annulment procedure or have their courts apply for a preliminary ruling, at the risk otherwise of becoming the object of an infringement procedure themselves or of incurring an action in state responsibility. The second situation is the case where the EC or the EU has no margin of appreciation either. This would be a Kadi-like situation in which member states are constrained by EU primary law and EU fundamental rights. They could not invalidate EU law themselves, but would be accountable in the context of an infringement procedure if they had not invalidated contrary national law nor seized the Court of an annulment application or have their courts require a preliminary ruling relative to the validity of the EU legal act at stake.

Finally, there may be a third category of cases in which member states are bound by UN Security Council resolutions without there being an EC regulation or an EU measure, hence falling outside the scope of application or derogation of EU law and as a result of EU fundamental rights. Although such cases are likely to be rare, they raise difficult issues. A first reaction would be to leave it to member states to solve conflicts between UN law and their other national and international duties. The position of other European jurisdictions, such as the European Court of Human Rights especially, would of course be crucial for the national decision. ${ }^{99}$ One may, however, also reverse the reasoning and argue on grounds of reciprocity that national law needs to respect EU fundamental rights also in purely national situations, and even more so in situations which affect interna-

${ }^{96}$ CFI, Case T-253/02, Ayadi v. Council [2006] ECR II-2139.

${ }^{97}$ CFI, Case T-228/02, People's Mojahedin Organization of Iran v. Council of the European Union [2006] ECR II-4665. See also most recently Case T-284/08, People's Mojahedin Organization of Iran v. Council of the European Union [2008] ECR I-0000, par. 75.

${ }^{98}$ ECJ, Case C-314/85, Foto Frost v. Hauptrollamt Lübeck-Ost [1987] ECR 4199.

99 This would be the case, for instance, if the ECtHR follows the ECJ's Kadi precedent in the Nada v. Switzerland case currently pending before it (n. 94). 
tional relations. This is the kind of reasoning that is used in Advocate-General Maduro's opinion in Centro Europa. ${ }^{100}$ If this kind of reciprocity argument pertains, a Kadi-based form of EU law-induced dualism would also apply here. ${ }^{101}$

\section{European pluralist dualism de lege ferenda}

\section{A plurality of legal pluralisms}

In light of the concerns identified within domestic legal orders in the aftermath of Kadi, the relationship between international and European law calls for a richer approach. In this context, there is one concept that has been regularly put forward to capture the relationships between legal orders in Europe: legal pluralism. The concept has developed especially in view of the limitations of the monism/dualism dichotomy ${ }^{102}$ and with respect to the current circumstances of legal consolidation and fragmentation in international and European law. ${ }^{103}$

Needless to say, legal pluralism is a complex concept. ${ }^{104}$ At least two dimensions of meaning need to be distinguished. In a first meaning, pluralism refers either to the plurality or multiplicity of legal norms or regimes applicable within the same legal order (internal legal pluralism) or, in a global context, to a multiplicity of legal orders whose norms can apply within each given legal order despite stemming from different legal orders (external legal pluralism). More and more these plural norms overlap, thus sharing the same material, personal and territorial scope. Of course, legal pluralism need not lead to normative conflict, but it may and this is how it usually attracts attention.

When pluralism is used to refer to a plurality of overlapping legal orders, it is usually distinguished from monism. ${ }^{105}$ As such, it constitutes an elaborate and

${ }^{100}$ AG Maduro, Case C-380/05, Centro Europa 7 [2008] ECR I-0000, par. 20.

${ }^{101}$ A recent decision by England's Court of Appeal seems to be going in that direction, without, however, mentioning EC or EU law at all: $A, K, M, Q$ and $G \mathrm{v}$. HM Treasury, judgment of 30 Oct. 2008 [2008] EWCA Civ 1187; [2008] WLR (D) 339.

102 On those limitations, see the introduction in Nollkaemper and Nijman, supra n. 35.

${ }^{103}$ I am consciously avoiding the term 'constitutional pluralism', as I am assuming that the autonomy of a legal order implies a rule of recognition and hence some kind of constitution. As a result, legal pluralism in the sense it is understood in this paper can only be constitutional pluralism. See also AG, Kadi, par. 21, by reference to ECJ, Case 294/83, Les Verts v. Parliament [1986] ECR 1339, par. 23.

${ }^{104}$ I am not looking here at moral pluralism or social and cultural pluralism, but only at legal pluralism. Nor am I considering non-official forms of law and social norms and hence those forms of pluralism of social norms. See, e.g., K. Günther, 'Rechtspluralismus und universaler Code der Legalität: Globalisierung als rechtstheoretisches Problem', in L. Wingert and K. Günther (eds.), Die Oeffentlichkeit der Vernunft und die Vernunft der Oeffentlichkeit (Frankfurt, Suhrkamp 2001) p. 539; J. Griffiths, 'What is Legal Pluralism?', 24 Journal of Legal Pluralism (1986) p. 2; W. Twining, Globalisation and Legal Theory (London, Butterworths 2000); Besson, supra $\mathrm{n} .3$ on those distinctions.

${ }^{105}$ Note that monism is a theory of legal validity within a given legal order and not of legal autonomy. Legal monism is entirely compatible as a result with the co-existence of separate autonomous legal orders, provided they do not overlap entirely. 
interlocking version of dualism. Legal validity does not, however, depend on transposition or reception in each other's legal orders, contrary to what is the case in a dualist legal order. What matters is that the validity of those different norms can be established together and at the same time in their respective legal orders, and this is best captured by the concept of inter-validity. ${ }^{106}$ Pluralism in this first meaning of the concept pertains therefore to the validity of legal norms. It assumes that the law's validity can have many autonomous sources within the same territory or community.

In a second meaning the term 'legal pluralism' refers to the equivalence of legal norms or of legal sources, either in the same legal order or between different legal orders. It provides a different answer to the question of primacy and rank of legal norms from the same legal order or from different legal orders overlapping in a given legal order. In that sense, pluralism is opposed to (formal) hierarchy of legal norms or sources; the presence of material normative hierarchies, that are transitive and hence apply across formal hierarchies of sources or of norms, is considered a feature of legal pluralism. Thus, the development of transitive human rights norms that apply across all legal orders (international, regional and national), such as jus cogens norms in particular, is usually qualified as evidence of legal pluralism. ${ }^{107}$

\section{European legal pluralism reconsidered}

Prima facie European legal pluralism provides a very attractive model when approaching the complex web of relationships among international, European and national law post-Kadi. It appears less restrictive than the dualist approach chosen by the Court in the relationship between European and international law, and would seem to alleviate the consequences of the primacy of EU law for domestic legal orders in their relationship to international law. It is also prima facie more compatible with the integrated nature of the European legal order and the relationship between national and European law, which some commentators have long qualified as being pluralist and not monist. ${ }^{108}$

Unsurprisingly therefore, legal pluralism was one of the three models available and defended in the Kadi case, and more precisely the one propounded by Advocate-General Maduro. Regrettably, legal pluralism was not clearly discussed as an alternative by the Court.

106 See Besson, supra n. 3, at p. 14; Günther, supra n. 104.

107 On those material hierarchies and the transnational constitution of human rights, see S. Gardbaum, 'Human Rights as International Constitutional Rights', 19:4 European Journal of International Law (2008) p. 749.

108 See, e.g., Maduro 2003 and 2007, supra n. 70; Günther, supra n. 104; Besson, supra n. 3. 
Appearances can be deceptive, however. Legal pluralism should not too readily be applied to all relationships between legal orders and to all legal orders. Issues of legal validity and of rank between legal orders are not contingent matters and ought to reflect key positions on the legitimacy of legal orders and norms. It is only by distinguishing more carefully between the legitimacy conditions of international, European and national law, and between questions of validity and rank that we can propose a convincing model of the relationship between legal orders in the EU. In what follows, therefore, I would like to argue that the best approach to the relationship between European and international law is neither the one propounded by the Advocate-General nor that of the Court.

The Advocate-General's opinion can be regarded as a blueprint of European legal pluralism. Maduro's legal pluralism is total: all relationships between all legal orders whose norms apply within the European legal order are characterized by pluralism. It concerns both the relationship between international and European law and that between European and national law ${ }^{109}$ and in all those relationships both the validity of legal norms stemming from different legal orders and their mutual rank. ${ }^{110}$

With respect to the validity of international law in the European legal order, the Advocate-General's approach comes very close to dualism. ${ }^{111}$ It is also possible, and more convincing, however, to reconstruct it along the lines of the account of inter-validity presented before. For instance, Maduro does not refer to the transposition or reception of international legal norms like the Court, but only to the permeation by those norms of the European legal order. ${ }^{112}$ This seems to indicate that the boundaries between legal orders are porous and can be perme-

${ }^{109}$ It follows from Maduro's academic writings that his approach to the relationship between national and EU law is a pluralist one. See, e.g., Maduro 2003 and 2007, supra n. 70. See also his opinions in Centro Europa (Case C-380/05, Centro Europa 7 [2008] ECR I-0000, par. 20), Arcelor (Case C-127/07, Arcelor [2008] ECR I-0000, par. 17) and Michaniki (Case C-213/07, Michaniki [2008] ECR I-0000, par. 31 et seq.).

${ }^{110}$ As far as I am aware of, Maduro does not clearly distinguish between those two dimensions of legal pluralism. They are deeply imbricated in his account, just as many accounts of legal monism are often correlated with accounts of the primacy of international law and, conversely, accounts of legal dualism with accounts of the primacy of national law. The conditions set by a legal order for norms from another one to become valid in that order also usually constitute norms of a higher rank in that order that condition and organize the primacy of those norms over internal ones.

${ }^{111}$ Pluralism and dualism differ imperceptibly prima facie when pertaining to validity: see M. Kumm, 'Democratic Constitutionalism Encounters International Law: Terms of Engagement', in S. Choudhry (ed.), The Migration of Constitutional Ideas (Cambridge, Cambridge University Press 2007) p. 256; S. Besson, 'Whose Constitution(s)? International Law, Constitutionalism and Democracy', in J. Dunoff and J. Trachtman (eds.), Ruling the World? Constitutionalism, International Law and Global Governance (Cambridge, Cambridge University Press 2009) p. 381; Besson, supra n. 3, at p. 12-15 for a discussion of the unicity of legal validity at any given time.

112 See AG, Kadi, par. 24. 
ated from either side, thus distinguishing the opinion's approach from a dualist one.

With respect to rank, Maduro's pluralism appears clearly: the key principle in the opinion is the equivalent protection of fundamental rights. ${ }^{13}$ It relies on the respect for a transitive material normative hierarchy: the material hierarchy of fundamental rights. What this means effectively is that once fundamental rights are equally protected in a given legal order's respective norms, that order's constitutional identity and autonomy ought to be respected. The Advocate-General, speaking on behalf of the European legal order, promises international law respect for its primacy once fundamental rights benefit from an equivalent degree of protection at the international level. ${ }^{114}$ This is the way the equivalence principle was applied by the German Federal Constitutional Court in Solange I and II to secure respect for a transitive material hierarchy of norms before granting primacy to European law over national law. ${ }^{115}$ Interestingly, at least if one reasons by reference to Maduro's position on the relationship between European and national law, pluralism is reciprocal: respect on the part of each legal order for the other's norms can and should take place on both sides of the relationship. As Maduro argues in Centro Europa, the Court should also apply that principle when national constitutions ensure an equivalent protection of fundamental rights to that of EU law. Once that protection is guaranteed on both sides, the constitutional identity and autonomy of both legal orders ought to be respected. ${ }^{116}$ In the Kadi case, Maduro's reasoning would therefore trigger duties of mutual respect on the part of UN authorities as well.

While pluralism may be the right model to capture the integrated nature of the European legal order, ${ }^{117}$ I would like to argue that it is not the right model for the

113 See AG, Kadi, par. 44.

${ }^{114}$ It remains unclear, however, whether this principle of equivalence applies outside the scope of EU judicial review to organise the rank of international law norms within the European legal order, and whether it also applies to all EU authorities applying European and UN law at the same time or only to the judiciary.

115 See Solange IBVerfGE 37, 271 (1974); Solange II BVerfGE 73, 339 (1986); and BrunnerBVerfGE 89, 155 (1993).

116 See AG Maduro's conclusions in Centro Europa (Case C-380/05, Centro Europa 7 [2008] ECR I-0000, par. 20). However, in Michaniki, the AG concludes, after having discussed the importance of recognizing Greek constitutional identity and the autonomy of its constitutional principles, that the primacy and unity of EU law requires giving priority to the EU rule over the Greek constitution in the specific case. By contrast, in Arcelor, both the AG and the Court confirm the choice made by the French courts to defer to the application of the European non-discrimination principle and hence emphasize the autonomy and hence the compatibility between constitutional identities (AG, Case C-127/07, Arcelor [2008] ECR I-0000, par. 19-27; ECJ, Case C-127/07, Arcelor [2008] ECR I-0000, par. 24). But, of course, this is at the price of the French courts giving priority to the EU principle based on their equivalence!

117 See Besson, supra n. 3, at p. 12-15. 
relationship between international and European law. Legal validity is shorthand for a claim to legitimacy and ought to entail the possibility for that claim to obtain. The autonomy of a legal order is not a merely legal phenomenon, but the reflection of a political reality: the polity's self-determination. As a result, all legal orders cannot be deemed as equivalent and their relationships cannot be organised in the same way in a comparable fashion, especially when they have individuals and States or only individuals as subjects. True, fundamental rights are protected in all three legal orders. However, while fundamental rights are an important condition of legitimacy and hence of legal validity, they are not the only one. ${ }^{118}$

The very refined demoi-cratic regime that was developed within the European legal order during the past fifty years can account for the legitimacy of EU law. It justifies a pluralist approach to the relationship between national and EU law within the European legal order. ${ }^{119}$ Democratic inclusion may be best guaranteed, depending on the cases, at the European level and this may grant certain EU law norms a higher democratic legitimacy. ${ }^{120}$ It is not (yet) the case at the international level, however: international human rights protection is not only deficient, but it also does not serve the same function as fundamental rights protection within the EU. More importantly, international law-making lacks the democratic dimension necessary to backup a claim to immediate validity and to constitutional rank within the European legal order. ${ }^{121}$ Paying due attention to that democratic requirement appears even more essential in an integrated legal order where validity in EU law also implies immediate validity within member states' national legal orders and democratic polities.

In its external dualist dimension, the Court's approach reflects a better awareness of the political conditions of legal validity and of the role of legitimacy in the recognition of the validity of the norms of another legal order, at least with respect to its own political interests. The Court does not mention the equivalence principle discussed in the Advocate-General Maduro's opinion, thus tacitly rejecting a pluralist approach to the relationship between the European and interna-

118 See for a detailed discussion, Besson, supra n. 111.

119 See Besson, supra n. 3; Besson, supra n. 111. See S. Besson, 'Deliberative demoi-cracy in the European Union. Towards the deterritorialization of democracy', in S. Besson and J.L. Martí (eds.), Deliberative Democracy and Its Discontents (Aldershot, Ashgate 2006) p. 188.

120 See, e.g., for an illustration of the link between fundamental rights and democracy, on the one hand, and of the relations between different levels of democratic government on the other, the rich test one may find in the reasoning of the Czech Constitutional Court in the 2006 Sugar Quota Regulation II judgment of 8 March 2006, Pl US 50/04 or in the 2006 European Arrest Warrant judgment of 3 May 2006, Pl US 66/04. It is particularly striking when contrasted with the Solange I or II tests used by the German Federal Constitutional Court that focus only on fundamental rights and conceive of the national polity as the only source of democratic legitimacy.

${ }^{121}$ See my critique of the AG's opinion in Kadi in this respect, Besson, supra n. 3, at p. 12-17. 
tional legal orders. There is no discussion as a result of a transitive catalogue of fundamental rights whose respect would be required across legal orders. The Court seems, however, to remain faithful to its own orthodoxy by sticking to a monist model in the relationship between EU and national law within the internal European legal order. ${ }^{122}$ In view of what was said before about the democratic justification of legal pluralism, the Court's internal monism cannot be entirely justified on democratic grounds.

So, while European legal pluralism could be defended as the most justified model of the relationship between national and European law on grounds of democratic legitimacy, that very legitimacy also explains why it cannot constitute the most legitimate model for the relationship between European (and national) law and international law. On the contrary, it is the Court's dualist model of the relationship between European and international law that best fits democratic requirements. Hence the concept of European pluralist dualism used at the outset of this section. ${ }^{123}$ Of course, one cannot exclude that the international legal order, or the UN regime at least, may at some point develop into an internal legal order with transnational dimensions on the model of the European legal order. This would, however, require accepting even deeper changes within national democracies than what has taken place in the EU since 1957. ${ }^{124}$ A 'Solange' threat of the kind expressed in the Advocate-General's opinion will not suffice in bringing about those institutional reforms at the international level.

\section{Conclusions}

In the wake of recent developments in EU law and in the international legal order, and in particular of the Kadi decisions, this article sought to shed new light onto classical questions raised by the relationship between European and international law. The questions and the answers that have traditionally been given have now been restated. The challenges raised by the Kadi case have also been unpacked and lie clearly ahead of us: they are numerous and complex and there are certainly many more than those that were identified in this contribution.

122 On that orthodoxy, see Besson, supra n. 3, at p. 7-11.

${ }^{123}$ Internal pluralism mitigates the difficulties external dualism may create for European member states that have a monist approach to international law. At the same, it entitles dualist member states to keep a certain democratic control on norms of international law deemed valid within the European legal order.

${ }^{124}$ On those challenges, see S. Besson, 'Ubi Ius, Ibi Civitas. A Republican Account of the International Community', in S. Besson and J.L. Martí (eds.), Legal Republicanism - National and International Perspectives (Oxford, Oxford University Press 2009) p. 204; S. Besson, 'Institutionalizing global demoicracy', in L. Meyer (ed.), Justice, Legitimacy and Public International Law (Cambridge, Cambridge University Press 2009) p. 58. 
Looking back, it is their eminently political nature that ought to be taken most seriously. Two conclusive remarks come to mind in this respect. One may wonder, first of all, whether questions that pertain to the constitutional self-determination of the Union are best raised and discussed by courts. At a time of disenchantment about the constitutional potential of treaty reform, it is easy to revert to the judiciary and vest it with a compensatory constitutional function. It is a well-known reaction in the EU, as the Court has regularly taken over from the constituent or legislative power in times of constitutional crisis. Taking 'no' for an answer does not rise to Europeans' ambitions, however. Nor to their legitimate political expectations.

One may also question, secondly, the EU-centred approach adopted in the Kadi case. In a municipal legal order of transnational dimension like the European legal order, the relationship to international law ought to start and end at the national level. The legitimacy of legal integration in Europe requires that national law and hence national democracy be taken seriously. This is why European legal pluralism is the most justified model of the relationship between national and European law. But this is also precisely why it does not constitute the most legitimate model for the relationship between European (and national) law and international law. Although this has rarely been sustained with success before and was not factored in by the Court in Kadi, we should not forget that, in Europe, it takes three to tango. 